\title{
EDITORIAL
}

\section{EXTENSÃO E FORMAÇÃO NA EDUCAÇÃO PROFISSIONAL}

\author{
Ilane Ferreira Cavalcante; Conceição Leal Costa; João Paulo de Oliveira; Olivia Morais de Medeiros Neta. Dante \\ Henrique Moura
}

\begin{abstract}
O que se pretende com o diálogo, em qualquer hipótese (seja em torno de um conhecimento científico e técnico, seja de um conhecimento "experiencial"), é a problematização do próprio conhecimento em sua indiscutível reação com a realidade concreta na qual se gera e sobre a qual incide, para melhor compreendê-la, explicá-la, transformá-la.
\end{abstract}

Paulo Freire, 2002

O conceito de extensão mudou ao longo do tempo, mas sempre esteve ligado à relação entre Universidades e Instituições com função de formação no ensino superior e a sociedade. Cada instituição estabelece o seu modelo e determina as formas como ela é desenvolvida. Mas ela sempre é um diálogo entre a comunidade acadêmica e a sociedade. Ela é um processo educacional que visa estabelecer uma prática de formação que leve à compreensão da realidade social e visa também levar o conhecimento produzido na comunidade acadêmica para fora de seus muros e trazer os conhecimentos sociais para as instituições educacionais.

Existem pelo menos quatro modelos de extensão utilizados pelas instituições de ensino superior ao longo da história: um que representa a transmissão vertical do conhecimento; aquele que se apresenta como voluntarismo, a ação voluntaria sócio comunitária; o modelo que se apresenta como ação sócio comunitária institucional; e o modelo acadêmico institucional. Evidentemente, tais modelos se apresentam de formas distintas em diferentes momentos e diferentes instâncias institucionais.

Para a Lei de Diretrizes e Bases (LDB) da educação brasileira, a extensão é uma das finalidades da formação em nível superior, que se articula a partir dos tripés ensino, pesquisa e extensão. Isso fica claro ao lermos os incisos II, IV e VII do artigo 43, da referida lei:

Art. 43. A educação superior tem por finalidade:

$[\ldots]$

II - formar diplomados nas diferentes áreas de conhecimento, aptos para a inserção em setores profissionais e para a participação no desenvolvimento da sociedade brasileira, e colaborar na sua formação contínua;

[...]

IV - promover a divulgação de conhecimentos culturais, científicos e técnicos que constituem patrimônio da humanidade e comunicar o saber através do ensino, de 
publicações ou de outras formas de comunicação;

\section{$[\ldots]$}

VII - promover a extensão, aberta à participação da população, visando à difusão das conquistas e benefícios resultantes da criação cultural e da pesquisa científica e tecnológica geradas na instituição.

(BRASIL, 1996).

Evidentemente, a LDB deixa entrever que na construção de seu discurso, diferentes formas de extensão e diferentes modelos conflitam em seu discurso, desde os modelos mais tradicionais, voltados para a transmissão do conhecimento produzido (inciso IV), com a ênfase nos verbos "promover" e "comunicar" até o diálogo e a colaboração em dupla via entre academia e sociedade, caso do inciso VII, que propõe que a abertura da participação da população na construção do conhecimento, embora que apenas difundindo as conquistas das produções institucionais. A LDB também não prevê a extensão como parte da formação no Ensino Médio, aspecto desenvolvido pelos institutos federais, e definido como uma das finalidades da rede de educação profissional e tecnológica na Lei 11.892/2009 (lei de criação dessas instituições). As reflexões presentes neste dossiê deixam evidente a lacuna da legislação acerca da importância da extensão na formação profissional e no ensino médio, em geral, assim como a relevância dos projetos de extensão desenvolvidos no diálogo entre a academia e a sociedade para a formação dos profissionais de nível técnico ou superior.

A diversidade de modelos, formatos e ações extensionistas foi o que instigou, em parte, a organização de um dossiê que pensasse a extensão sob a perspectiva não só da formação geral, mas da educação profissional. Um conjunto de reflexões que reúne pesquisadores de várias instituições brasileiras (institutos federais e universidades) e que conta com a colaboração, na editoração e no corpo de produções, da colega Conceição Leal da Costa da Universidade de Évora.

O conjunto de reflexões, experiências e práticas aqui reunido traça um retrato da diversidade das ações de extensão e das perspectivas teóricas, sociais, educacionais que movem as instituições de educação básica e superior em seu diálogo com a sociedade e permite o registro desse momento para a construção histórica da extensão no Brasil.

Boa leitura! 